\title{
How Political is Political Consumption? The Case of Activism for the Global South and Fair Trade
}

\author{
Jörg Rössel and Patrick Henri Schenk
}

\author{
University of Zurich
}

\begin{abstract}
Political consumption is a flourishing field of research at the intersection of consumer research and political sociology. Political consumption means the consideration of ethical or political motives in the decision to buy certain products. Its main forms are the buying (buycott) of products distinguished by certain ethical or political characteristics such as sustainability, social justice, or corporate responsibility, and the boycott of products that lack such characteristics. However, there is an ongoing discussion about the status of political consumption. Some authors suspect that it may distract citizens from more challenging forms of participation (crowding-out thesis). In contrast, most empirical research has shown that political consumers are also more active than the general population in other forms of political participation. However, this has only been shown for fairly general measures of political consumption and participation. Our contribution to this debate thus focuses on one specific form of political consumption and corresponding forms of participation: activism for the Global South and fair trade consumption, zooming in on the case of Switzerland, where fair trade consumption is quite widespread within the population. Our results show that fair trade consumption is only weakly related to other forms of engagement for Global South issues, thus it does not distract from more challenging forms of engagement, but it is also not part of a more general engaged lifestyle. This is supported by the fact that the motivations and structural underpinnings of other forms of activism for the Global South differ from those of fair trade consumption.
\end{abstract}

KEYWORDS: political consumption; political participation; fair trade; Global South activism; crowding out.

In recent years, sociologists, political scientists, and psychologists have established a new and flourishing field of research at the intersection of consumer research and political sociology, the field of political consumption (Barnett et al. 2005; Lorenzen 2012; Mazar and Zhong 2010; Raynolds 2002; Stolle, Hooghe, and Micheletti 2005; Sunderer and Rössel 2012; Szasz 2007; Willis and Schor 2012; for reviews see Andorfer and Liebe 2012 and Newholm and Shaw 2007). Basically, political consumption means the consideration of ethical or political motives in the decision to buy or boycott certain

A previous version of this article was presented at the 2013 Annual Meeting of the American Sociological Association. The authors wish to thank Veronika Andorfer, Sebastian Koos, and Georg Sunderer, as well as the journal's reviewers, for valuable feedback. This research was supported by the Swiss National Science Foundation (SNSF). Direct correspondence to: Jörg Rössel, University of Zurich, Andreasstrasse 15, 8050 Zurich, Switzerland. E-mail: roessel@soziologie.uzh.ch. 
products or brands, with the goal of changing institutions, organizations, or social conditions (Koos 2012; Stolle et al. 2005; Yates 2011). The main forms of political consumption are, on the one hand, the positive buying (buycott) of products distinguished by certain ethical or political characteristics such as sustainability, social justice, or corporate responsibility, and, on the other hand, the boycott of products that lack such characteristics.

According to survey results, both forms of political consumption seem to be widespread in the population of advanced capitalist countries, with up to 60 percent of the population in countries such as Sweden and Switzerland buycotting certain products, and up to nearly 40 percent having participated in the boycott of brands and products (Koos 2012; for the United States, cf. Willis and Schor 2012). Thus political consumption is not only an academic field of research, but an increasingly widespread attempt to influence corporations and politicians by market choices (Bennett 1998; Dalton 2008).

However, there is an ongoing discussion about the status of political consumption. Is consuming or boycotting certain products and brands really comparable to political participation as a citizen? Some authors suspect that political consumption may distract citizens from actual political participation-with adverse consequences. According to Andrew Szasz (2007), political consumption has to be seen as part of a neoliberal political culture that fosters individualism, shifts responsibility to the consumer, and erodes civic responsibility (cf. Johnston and Szabo 2011). Political consumption, therefore, effectively works as a mild substitute for other forms of political engagement because "rather than inspiring additional action, ethical consumption is more likely to silence the internal voice that urges us to do more" (Szasz 2012:79; cf. Mazar and Zhong 2010). In this view, political consumption undermines more radical approaches to institutional political change, which might be much more politically effective (Balsiger 2012). Furthermore, some scholars have claimed that political consumption is a complex phenomenon, with consumers oscillating between ethical and aesthetic concerns, but partially this form of consumption could also represent a form of distinction by upper middle-class consumers who are able to buy expensive, ethically sound food and thereby feel more ethically distinct than consumers from a lower class (Adams and Raisborough 2008; Johnston and Baumann 2010).

Researchers in the field of political consumption counter these arguments by focusing on the socalled "crowding-out" thesis. It posits that political consumption undermines an actor's propensity to engage in other forms of activism. The question is then: "Does political consumption distract citizens from other, more challenging, forms of political participation?” Although still open to debate, most studies suggest that this is not the case. While some contributions do provide evidence for a possible crowding out (Mazar and Zhong 2010; cf. Monin and Miller 2001; Sachdeva, Iliev, and Medin 2009), most empirical research has shown that political consumers are also active in other forms of political engagement (Baumann, Engman, and Johnston 2015; Stolle et al. 2005; Willis and Schor 2012). Up until now, however, this has only been shown for fairly general measures of political engagement. Few studies have focused on more specific measures of political consumption and their relationship to corresponding forms of political participation. The results of these studies are rather mixed (Willis and Schor 2012).

Our contribution to this debate, therefore, focuses on one specific form of political consumption and participation: activism for the Global South. The term "Global South" refers to poor and disadvantaged countries in the southern hemisphere. It is not merely a geographical but primarily a sociopolitical category (Omeje 2008). Activism for the Global South therefore implies political action with the goal of changing social circumstances in these countries and of altering exchange relations between the Global South and Global North (for research on Global South activism cf. Bair and Palpacuer 2012; Summers 2016).

This is of course related to fair trade consumption (Andorfer and Liebe 2012). Fair trade seeks greater equity in international trade in order to improve the livelihoods of farmers and workers in the Global South (Max Havelaar 2012). It involves labeling organizations that certify products, alternative 
trade organizations (ATO) that maintain direct trading relationships with producers, and campaigning organizations that advocate fair trade in national and international forums (Wilkinson 2007). However, in our study we employ a narrow definition of political consumption that only involves the first two components of fair trade, namely the purchase of certified fair trade products or products imported by fair trade organizations.

Prior research on fair trade investigated the organization of the global commodity chain for fair trade products (cf. Jaffee 2012; Raynolds 2002), the impacts of fair trade in producing countries (cf. Le Mare 2008), and the demand for these products (cf. Andorfer and Liebe 2012). In contrast to these studies, we investigate the relationship between the consumption of fair trade products as one prominent type of buycotting and other forms of political engagement for the Global South.

Focusing on a specific issue is crucial because prior empirical research established that different types of political consumption are related to different explanatory variables. A prime example concerns fair trade and organic consumption. While the former is foremost dependent on the educational background of the consumer, the latter is more strongly influenced by income (Mahé 2010). Additionally, attitudes concerning fair trade are only moderately correlated with ecological concerns (Balderjahn, Peyer, and Paulssen 2013). Therefore, the mechanisms, which connect different forms of political engagement (and thus possibly generate a crowding out), may be sensitive to the particular issue at hand. Furthermore, we include motivational determinants such as attitudes and values, besides structural variables, and are thus able to arrive at a more fine-grained picture of the differences between the separate forms of political engagement. Finally, we study survey data from Switzerland, where fair trade consumption is widespread in the general population (Mahé 2010; Max Havelaar 2012).

Our results show that fair trade consumption is quite weakly correlated to other forms of political engagement for Global South issues. Moreover, the determinants for fair trade consumption seem to differ from the motivations and structural underpinnings of other forms of activism for the Global South. In general, our results move beyond the crowding-out thesis and establish a more differentiated image of political engagement for the Global South and the varying determinants of its different manifestations.

\section{POLITICAL CONSUMPTION: THEORY AND CONTROVERSY}

\section{What is Political About Political Consumption?}

As an instrument for social and economic change, political consumption represents an increasingly important form of political engagement (Dalton 2008). For example, the share of people in European countries who boycotted certain products was around five times as large in the early 2000s as it was 30 years before (Koos 2012; Stolle et al. 2005). In the same vein, the sales of fair trade products in Switzerland increased by a factor of four in ten years starting in the 2000s (Max Havelaar 2002, 2012).

In contrast to other forms of political participation like voting, contacting a politician, being in a political party, or participating in strikes, political consumption represents an individualized form of political participation outside of the formal institutions of the political system and has therefore been characterized as "subpolitics" by Ulrich Beck (1997) or as "individualized collective action" by Michele Micheletti (2010). The notions of individualized collective action or subpolitics stress the individual and non-institutionalized nature of political consumption. Yet, this view has not gone uncontested. A key objection is based on the fact that consumer power can only become effective if a large enough group of people buycott or boycott a certain product. For this reason, collective actors that mobilize consumers and furnish a collective identity play an important role in this process (Balsiger 2010). The extent to which consumers see themselves as part of a larger movement is likely to vary within the field. While a collective identity is highly salient for people who are deeply involved with fair trade (vendors, activists, etc.), the general fair trade consumer might not see himself as a member 
of a movement but rather as a critical consumer who contributes to a good cause (Brown 2009). Still, the campaigning activities of social movements are crucial for all consumer types, since they imbue the purchase of fair trade products with political and moral meaning and thereby establish the opportunities for political consumption (Balsiger 2012; Barnett et al. 2005). This objection implies, firstly, that effective political consumption depends on collective action and is therefore not completely different from other forms of political action, such as strikes, demonstrations, and violent confrontations. Secondly, political consumption is embedded within larger social movements that struggle for political influence.

On the macro-level, then, political consumption represents a strategy to attain political objectives, employed and sustained by social movements. Political consumption, however, is usually only one form of political activism in a social movement field. According to Philip Balsiger (2012), the strategies of the different social movement organizations are interdependent. Although they can be complementary, they may also be in conflict with one another. This suggests that the pursuit of one political strategy may alter the conditions and therefore generate or eliminate incentives for actors to participate in another form of political action. Are actors, for example, still motivated to take part in more radical action, such as demonstrations or blockades, if they can otherwise engage in a more passive and individualized form of political activism, such as political consumption?

With regard to this issue, two different positions have emerged in the debate. On the one hand, there is the view that political consumption undermines an actor's propensity to engage in more challenging forms of activism. This proposition has been termed the crowding-out thesis. In the context of this article, we define a "crowding out" as the displacement of a certain form of political participation as a consequence of political consumption (cf. Willis and Schor 2012). Such a displacement may be due to limited resources for political activism. Issue-specific, market-based forms of engagement are rather easy and can drain the political resource budget, which, in turn, may hinder any further involvement in other forms of engagement (Bennett 1998; Johnston and Szabo 2011). Furthermore, research on "moral licensing" suggests that people who consume politically might feel they have fulfilled their moral obligation and thus refrain from other political activities for the Global South (Mazar and Zong 2010; Monin and Miller 2001; Sachdeva et al. 2009). Hence, a restricted time budget or a moral licensing effect might produce a crowding out: people who consume politically abstain from other, more challenging forms of political engagement. This would manifest itself in negative correlations between political consumption and other forms of Global South activism.

On the other hand, some scholars have argued that political consumption and political participation can be mutually reinforcing and thus create a lifestyle of conscious consumption and activism (Willis and Schor 2012). Different forms of Global South activism might form a coherent lifestyle insofar as they are based on the same determinants. Firstly, resources that are necessary for the pursuit of a certain form of Global South activism may also facilitate engagement in other forms of political participation (Lorenzen 2012). Economic capital (money), cultural capital (education, knowledge), or social capital (organizational membership) might be of importance here (cf. Verba, Schlozman, and Brady 1995). Furthermore, specific forms of activism lead to the acquisition of resources-such as skills-which can contribute to stronger engagement in other forms of activism. Secondly, basic beliefs such as values or political worldview can motivate consistent behavior across different situations (Schwartz 2007).

However, it does not follow from the argument that such a lifestyle will be entirely coherent. People might willfully ignore the ethical consequences of their decisions in certain situations despite having a strong value commitment (Ehrich and Irwin 2005); particular events such as personal travel experiences might be necessary to articulate political preferences for Global South activism (Brown 2009) or their lifestyle might have a "provisional coherence" if there is an ongoing process of lifestyle change (Lorenzen 2012). Nevertheless, and contrary to the crowding-out thesis, this argument implies that different forms of political activism tend to be positively correlated and that any 
fragmentation of a lifestyle of conscious consumption will partly be a function of the determinants of the different forms of political participation.

Empirical research has tended not to support the crowding-out thesis, in spite of some experimental evidence supporting the idea of a moral licensing effect (Mazar and Zong 2010). Either the relationship of political consumption with other forms of political participation was found to be nonexistent (Stolle et al. 2005) or a positive relationship between them was established (Baumann et al. 2015; Willis and Schor 2012). However, most studies have focused on fairly general measures of political consumerism and participation. In the analysis by Margaret Willis and Juliet Schor (2012), more specific measures of political consumption in particular areas (e.g., energy, transportation, water) were used. Here, the results were mixed. Certain forms of political consumerism correlated positively with other forms of political activism, others did not. This indicates a need for further research on specific forms of political consumption and its relationship to other specific forms of political activism.

In brief, in order to further clarify the status of political consumption, we need to assess whether this form of political engagement correlates positively or negatively (crowding out) with other and especially more challenging forms of political activism. A reason for the lack of conclusive evidence for or against the crowding out thesis might be that the thesis has mostly been investigated for general measures of political consumption (Baumann et al. 2015). The relationship between specific forms of political action remains unclear (cf. Willis and Schor 2012). Before turning to the empirical investigation of this question in relation to the issue of Global South activism, we want to discuss the determinants that may foster or inhibit participation in different forms of political engagement.

\section{Explaining Participation in Different Forms of Political Activism}

In the political sciences as well as in political sociology, an important line of research concerns the socioeconomic stratification in the use of political means, often referred to as a "participation gap" (Acik 2013). One prominent approach used to explain these differences is the model of voluntary political participation, which places a special emphasis on the resources that enable people to participate politically (Verba et al. 1995). In particular, money and civic skills are of crucial importance. The latter consist of organizational abilities as well as the capacity for successful communication. These skills are primarily transferred via social institutions outside the political system, especially the family, schools, the workplace, and religious institutions (Verba et al. 1995). Thus the model of voluntary political participation implies that income as well as formal education can be expected to have a positive effect on different forms of political participation.

However, empirical research has revealed a participation gap not only in terms of income and education, but also in terms of gender, age, and nationality (Acik 2013). When it comes to political participation in general, women are theorized to have less access to the resources described above, and to be less politically engaged (interest, sense of efficacy, etc.), due to a gender-specific socialization (Coffé and Bolzendahl 2010). Empirically, several studies have found that women participate less in institutionalized forms of politics (such as voting, being in a political party, etc.) and in demonstrations, while the reverse is true for buycotting and signing petitions (Coffé and Bolzendahl 2010). Scholars suggest that the higher rate of political consumption among women may be because the role of women in Western societies entails responsibility for the shopping (cf. DeVault 1991) or because women are socialized to be more caring, empathic, and prosocial (Bierhoff 2002). Gender norms for women, therefore, not only bring about better opportunities for political consumption but also foster motivations that encourage political consumption. When it comes to age, there is still disagreement about whether life cycle or cohort effects explain differences in political participation between age groups. Based on empirical evidence, however, the majority of studies conclude that younger or middle-aged individuals participate more often in forms of political activity outside of the formal channels of the political system than older citizens (Acik 2013; Micheletti and Stolle 2005). 
In our study, we are able to move beyond an explanation based on the sociodemographic covariates discussed so far, by including an array of motivational determinants. Firstly, we consider two kinds of attitudes (Ajzen and Cote 2008). We hypothesize that a left-wing political orientation will lead to a skeptical evaluation of the problems in the Global South and thus a higher propensity for Global South activism. In addition, following the concept of environmental consciousness, we developed a measure that reflects the attitude of the individual towards the exploitation of farmers and workers in countries of the Global South (Preisendörfer and Franzen 1996). We assume that individuals with a pronounced "Global South consciousness" participate more often (Sunderer and Rössel 2012).

Secondly, we theorize that accepting responsibility for the exploitation and poverty of people in the Global South predisposes individuals to participate politically. Ascription of responsibility is one of the central determinants in Shalom Schwartz's (1977) norm activation model, which has been successfully applied to pro-environmental behavior-a subject closely related to political consumption and other forms of activism (cf. Blamey 1998; Stern et al. 1999). The belief that one bears responsibility for the poverty of the people in the Global South represents a strong motivation for Global South activism besides the aforementioned attitudes.

Thirdly, we refer to the value orientation of the individual in order to explain political participation. In contrast to attitudes and ascription of responsibility, which target the specific issues of exploitation and poverty in the Global South, values are beliefs that transcend specific situations, guiding the selection and evaluation of behavior (Schwartz 2007). Schwartz (2007) distinguishes between ten different value types. In this study, however, we restrict the analysis to three value types that have been deemed especially important for the explanation of political consumption: universalism, benevolence, and self-direction (Doran 2009; Ma and Lee 2011). The first two value types belong to the higher-order dimension "self-transcendence," and express a prosocial orientation (Schwartz 2007). "Benevolence" reflects the concern for the welfare of close others in everyday interaction. "Universalism" describes the motivation to understand and protect the welfare of all humans and the environment. The third value type is "self-direction," which implies the goals of independent thought and action. In line with prior research (Doran 2009; Ma and Lee 2011), we expect that all three value types will yield a positive influence on political activism.

Finally, we want to assess whether religiosity has an impact on political participation. Here, however, the exact nature of the theoretical mechanism remains unclear. On the one hand, in line with the civic voluntarism model outlined above, participation in a religious institution fosters civic skills and could therefore strengthen political participation (Verba et al. 1995). This is highly plausible in this case, since the movement for Global South activism has strong links to church organizations, and religiosity might therefore foster participation in this movement. On the other hand, religiosity can be associated with strong ties to the social in-group, and might therefore inhibit prosocial behavior towards distant others, i.e., people in the Global South (Preston, Ritter, and Hernandez 2010). Consequently, we simply hypothesize that religiosity has an effect on political engagement, without specifying the direction of the relationship.

\section{RESEARCH QUESTIONS AND STRATEGY}

Previous research has revealed that political consumption does not crowd out other forms of political activism. However, there is a lack of evidence on more specific forms of political consumption and political engagement. Therefore, unlike previous studies, where the items used to measure political consumption are formulated in very broad and abstract terms (e.g., "Have you ever bought products for ethical, political, or environmental reasons?"), the political activities we are looking at are all targeted at the same concrete issue: support for people in the Global South. We are therefore able to study the crowding-out thesis with a much more specific focus than usual. 
We employ two different statistical approaches in order to assess whether and in what way political consumption relates to other forms of political participation. Firstly, we want to examine the intercorrelations of political consumption (buycotting and boycotting) with other forms of political participation. Do the different activities form one coherent lifestyle? If this were the case, we should receive a one-factorial solution in a principal component analysis (PCA) with all measures of Global South activism. Although this method allows us to assess the dimensionality of political participation, it involves a major shortcoming. The principle component analysis yields the correlations of the different forms of participation with the latent factor (the factor scores), but it does not indicate which practices are pursued more often in combination with other practices, e.g., buycotting more often with boycotting than with demonstrations. We therefore also perform a multiple correspondence analysis (MCA). Basically, MCA is a statistical method that transforms a contingency table into a low-dimensional, geometrical space (Le Roux and Rouanet 2010). It yields a graphical representation of the distribution of certain categories and variables. For our application, we chose a two-dimensional representation, which we interpret as a space of Global South activism. Categories with a similar distribution (which are pursued by the same set of individuals) are represented by points that are close together in this space. Points that lie far apart indicate dissimilar distributions. Hence, by looking for clusters of points in the MCA we are able to attain a more fine-grained picture about which forms of political participation are pursued by the same people and which are not.

Secondly, our approach rests on a comparison of the sociodemographic and motivational determinants for the different forms of political participation. As explained above, the idea that political consumption is part of a broader lifestyle of political participation implies that individuals with the same sociodemographics and motivations will participate in the same forms of political activism. This, however, should become visible in similar determinants of the various forms of activism. If different forms of political participation differ in their social and motivational determinants, this indicates significant differences between its carrier groups.

Since our dependent variables are measured on a three-point ordinal scale, we computed a series of ordered logit models in order to compare the determinants for the different forms of political participation. To compare the statistical effects we use two techniques (Mood 2010): Firstly, we standardize the raw $b$-coefficients by dividing them by the estimated standard deviation of the latent dependent variable $\left(y^{*}\right){ }^{1}$ Thus, the $y^{*}$-standardized $b$-coefficients depict the change in standard deviations in the latent continuous variable $y^{*}$ for a unit change in the independent variable. Secondly, to supplement this analysis we use the average marginal effects (AME) for a comparison of the determinants. To simplify the task, however, we will only consider the AME for the third category of the dependent ordinal variables ("yes, several times/regularly"). Plotting the AME and the 95 percent confidence interval for a single determinant against the different forms of political participation offers us a convenient way to assess similarities and differences of the correlations between the explanatory and the dependent variables.

\section{Data and Measurement}

For the empirical analysis we use data from a standardized mail survey carried out in Zurich, Switzerland, in 2011. The population comprises people who are over 18 years of age and reside in Zurich. The sampling procedure consists of a stratified random sample. We contacted 5,000 inhabitants with Swiss citizenship and 1,000 inhabitants with German citizenship, chosen randomly from the register of permanent residents. ${ }^{2}$ After eliminating questionnaires with a large number of inconsistent responses and taking neutral sampling failures into consideration, the adjusted response rate

1 Due to the problem of unobserved heterogeneity, we cannot compare the raw b-coefficients across the models (Mood 2010).

2 The German subsample was chosen for comparative purposes, since we also conducted a survey in Germany. Citizenship serves as a control variable in all models. 
of the survey is 42 percent. $^{3}$ In contrast to other studies that based their analysis on convenience samples or special populations (cf. Stolle et al. 2005), this procedure enables us to analyze the general urban population, and not only people who engage in political consumption. Switzerland is an especially interesting research site for this form of participation since it exhibits a very mature and partially saturated market for ethical products (Mahé 2010). In 2011, it was among the leading countries in the consumption of fair trade products per capita with 33 Euros, compared to Ireland with 35 Euros or the UK with 24 Euros (FLO 2012). Furthermore, the market share for certified bananas was very extensive with 55.3 percent and the market share for certified coffee, although smaller, was still considerable for fair trade with 5.3 percent (Max Havelaar 2012).

\section{Dependent Variables}

We use six different forms of political participation as dependent variables. These include: buycott, boycott, signing a petition, participation in a demonstration, donating money, and participation in voluntary organizations. Except for the buycott variable, we asked respondents directly whether they had ever used one of these activities to help people in the Global South. Participants could give an answer on a scale from one to three with: (1) "Never," (2) "Yes, once," and (3) "Yes, several times/regularly." We computed the buycott variable, on the other hand, from the self-reported frequency of purchasing fair trade groceries. Fair trade products are by definition intended to support producers and employees in countries of the Global South. We recoded the original scale, consisting of seven categories, into three categories that are similar in meaning to the other items of political participation. ${ }^{4}$

\section{Independent Variables}

In terms of the structural position of individuals, we refer to the gender, nationality, age, income, and education of the participant. Gender is a binary variable, with women coded as 1 and men coded as 0 . Nationality is also a binary variable: 1 represents German and 0 Swiss living in Zurich. We use age as a metric variable. For income, we calculated the equivalent household income, which weights the total monthly income of a household by its size and the age of its members. Education reflects the highest level of education achieved and is measured by three different levels: "higher education" comprises participants with a university degree or other form of higher education, "intermediate education" consists of schoolleaving qualifications giving access to higher education (the "Matura" in Switzerland), and "lower education" covers respondents who have completed the compulsory minimum level of education.

To measure religiosity, we asked participants how often they generally attended religious services. This is an especially useful operationalization since it captures the strength of the respondent's integration into the church community, which is often a supporter of activism for the Global South and a place to learn civic skills (cf. Verba et al. 1995). We computed a variable with three values: "never," "rarely to several times a year," and "more than once a month."

We rely on two attitudinal constructs to explain activism for the Global South. Firstly, the political orientation of the participant was measured on a ten-point scale, with low values indicating a leftwing and high values a right-wing orientation. We trichotomized the variable for the analysis,

3 The elimination of questionnaires was part of the data cleaning procedure, in which we primarily checked for inconsistencies between items that belonged to the same attitudinal measure (cf. Mitchell 2010). Once inconsistencies were identified, we examined the questionnaire globally and made a decision as a research team whether or not to include it in further analysis. It is important to stress that this procedure did not apply to the measurements of political participation. Thus, the data cleaning procedure did not affect the extent to which the forms of political participation are consistent, i.e., whether the data points to a crowding out or a coherent lifestyle. In any case, our results are robust to the elimination of these questionnaires. Furthermore, compared to other surveys of the general population we achieved a rather high response rate. On the one hand, this is due to the survey design, which followed the Tailored Design Method (Dillman 2000). We sent two reminders to participants who did not respond to our first letters. On the other hand, we framed the survey as a general opinion poll about food choices and politics, which is a topic of general interest in Switzerland.

4 The original categories are: (1) "never," (2) "once a year or less," (3) "several times a year," (4) "once a month," (5) "two or three times a month," (6) "once a week," and (7) "more than once a week." 
resulting in the categories "left," "center," and "right." Secondly, we developed a measure entitled "Global South consciousness," consisting of a four-item additive index. Each item has a range from 1 to 5 , with the lowest value indicating total disagreement with the statement and the highest total agreement. The measure reflects the respondent's attitude towards the exploitation of famers and workers in the Global South. A sample item is: "I am willing to do something against the exploitation of farmers and workers in the Third World countries." The reliability of the index is very good, with a Cronbach's alpha of .79 .

Apart from the influence of attitudes, we wanted to test whether the perception of who has responsibility for the exploitation and poverty of people in the Global South affects the propensity to participate politically (Blamey 1998; Schwartz 1977). Based on an exploratory factor analysis we computed three different subscales: (1) The responsibility lies with the people in Switzerland, i.e., the consumers, (2) institutions are responsible, namely the government, governmental organizations and the business world, and (3) the producers in the Global South themselves are responsible. The reliabilities of the scales range from a Cronbach's alpha of .79 to .82 .

Finally, we measured the value orientation of the participant with the 21 -item version of the portrait value questionnaire developed by Schwartz (2007). For reasons of space, we restricted the survey to three value types (Doran 2009; Ma and Lee 2011): universalism, benevolence and selfdirection. ${ }^{5}$ Cronbach's alpha for "universalism" is .58, for "benevolence," .57 , and for "self-direction," .42. These coefficients are moderate but of similar magnitude to those in other studies using the portrait value questionnaire (Schwartz 2007:181).

\section{Empirical Results}

The research questions in our contribution are twofold. Firstly, we want to know whether our data supports the crowding-out thesis: are the different forms of Global South activism-in line with the crowding-out thesis-negatively interrelated or are they pursued in conjunction, as the idea of a coherent lifestyle suggests? Our second question is directed at the social and motivational determinants of the different forms of Global South activism: do they have the same structural and motivational underpinnings or can we observe differences between these forms of political participation? The answer to the second question is also related to the first, insofar as it enables us to interpret the intercorrelations between different forms of engagement in a meaningful way, based on their differing or shared determinants.

We studied the first question by conducting a principal component analysis (PCA) and a multiple correspondence analysis (MCA) of the six measures of Global South activism. With regard to the PCA, the results in Table 1 show that all items load on one dimension. The results thus indicate one single scale of activism for the Global South, of which political consumption in the form of boycott and buycott are two parts. However, there are two reservations to this conclusion. Firstly, overall explained variance is rather low, which suggests that the six forms of participation do not form a coherent lifestyle of Global South activism. Secondly, two factor loadings stand out as particularly low: on the one hand the factor loading for buycott (buying fair trade products), and on the other hand the factor loading for donations. In Switzerland these are both fairly common activities. The share of the population involved is therefore much higher than for other forms of activism for the Global South, and only a subgroup combines these two activities with more challenging forms of political participation.

These conclusions are confirmed by the MCA (see Figure 1). First of all, the majority of the variance is captured by the first dimension, indicating that the different forms of political engagement are related. Secondly, we can infer from the relative position of the categories that buycotting and donations are fairly undifferentiated forms (i.e., participated in by the majority of the respondents), as 
Table 1. Principal Component Analysis of Different Forms of Political Participation (varimax rotation)

Factor Loads

Buycott

Boycott

Petition

Demonstration

Donation

Organizations

Eigenvalue factor

Explained variance (\%)

KMO

Cronbach's alpha

$N=1,811$

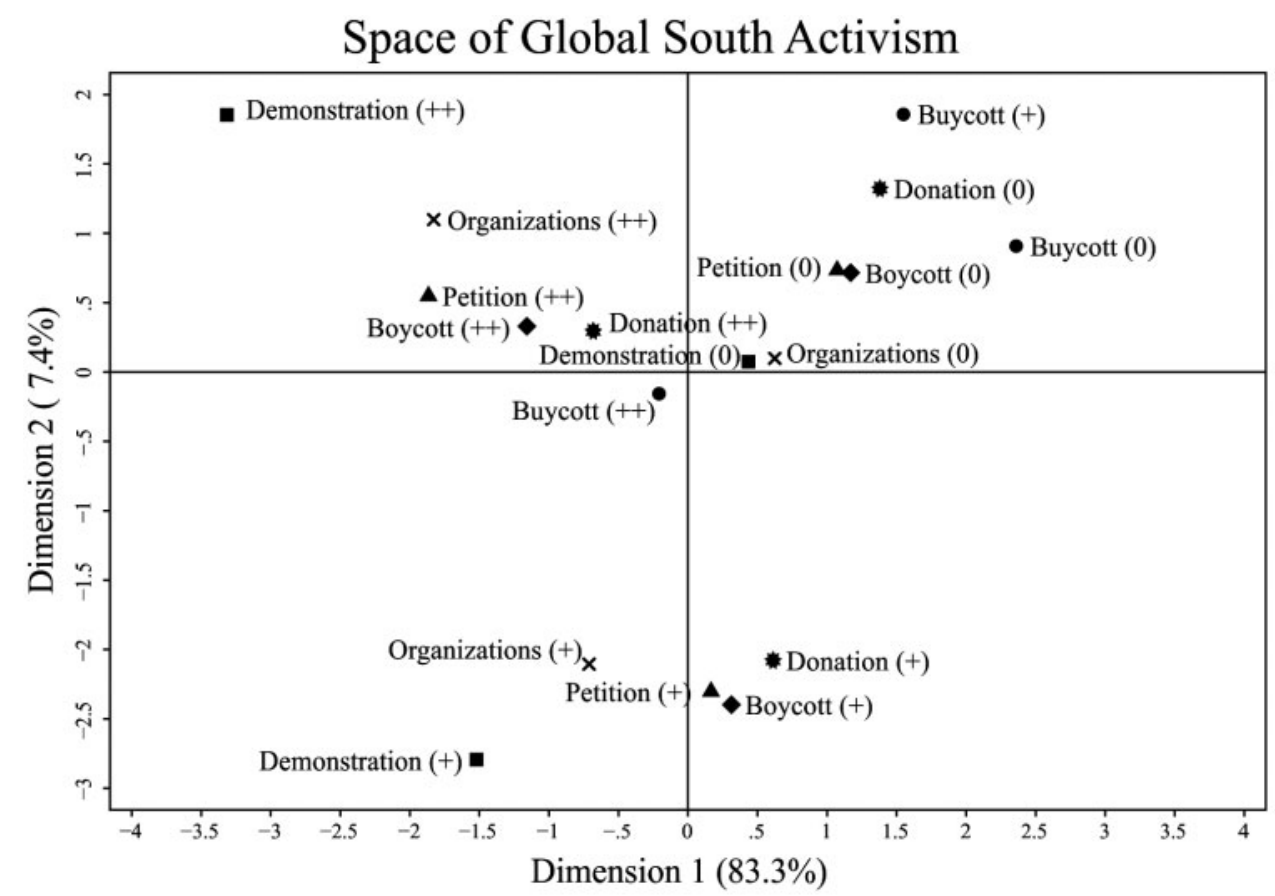

Figure 1. Multiple Correspondence Analysis of Different Forms of Political Participation (standard normalization)

Notes: $N=1,811 ; 0=$ never; $+=$ yes, once; $++=$ yes, several times/regularly.

they are situated close to the origin of the biplot, while regularly joining a voluntary organization and-especially-participating in a demonstration stand out in the geometrical space. The proximate positions of buycotting and donating regularly on the one hand, and never demonstrating or participating in voluntary organizations on the other, reflect the fact that even respondents who never demonstrate or join voluntary organizations still buy fair trade products and donate money on a regular basis.

Taken together, these results do not support the crowding-out thesis: political consumption and other more challenging forms of political participation do not seem to hinder each other. However, 
the results also indicate a certain segmentation of the six forms of Global South activism and, interestingly, the placing in different segments of the two types of political consumption: in one segment we find the more mainstream forms of buycotting and donating, and in the other, we see the more demanding forms such as boycotting, signing a petition, joining a voluntary association, and demonstrating. These can be characterized as more demanding because they are either dependent on specific knowledge (i.e., cultural capital) in the case of boycotting or the opportunities for these forms of political participation are rarer, such as in the case of signing a petition, joining a voluntary association and demonstrating. For example, while fair trade products are abundant and clearly labeled in Swiss supermarkets (approximately 1,600 products were available in the year 2011; Max Havelaar 2012) to boycott products one needs to obtain information about good or bad practices of firms from particular sources (cf. Balsiger 2010). The boycott of Nestlé products, for instance, which took place around the time of the survey and after the firm's practice of privatizing water rights received public attention, presupposes a lot of knowledge on the part of the consumer about the company's products and structure (cf. Ulrich 2013). Likewise, while it is common practice to receive appeals for donations by mail in Switzerland (for example from "terre des hommes," a children's charity), opportunities for signing a petition are rather rare since in Switzerland signatures are mostly collected by activists on the street (cf. Schulthess 2015).

Still, a closer look at the MCA (see Figure 1) reveals that even among the more demanding forms there is a certain separation between boycotting and signing a petition on the one hand and demonstrating and joining a voluntary association on the other. This strengthens our interpretation: the more demanding a certain form of Global South activism, the lower the likelihood that it is combined with other activities. For example, members of the anti-globalization movement attac-bern-a voluntary association-are expected to be present at special events, to campaign and mobilize actively, or to participate in protests against the World Economic Forum in Davos (Switzerland) (attac-bern n.d.). This radical form of political activism is clearly more demanding than political consumption and signing a petition

Based on these findings, we may conclude that there is only a subgroup of consumers in our sample for whom political consumption constitutes part of a lifestyle of active engagement. Political consumption in the form of buycott does not seem to be very different from donations, a very traditional form of participation. Most consumers, with the exception of the very engaged subgroup, seem to "willfully ignore" more demanding possibilities for political engagement with Global South issues, which results in a rather fragmented lifestyle with only limited coherence (Brown 2009; Ehrich and Irwin 2005; Lorenzen 2012).

To address our second question, we analyzed the determinants of all six forms of activism for the Global South. The empirical results of the ordered logit regressions are presented in Tables 2 and 3. Our first step is to look at the model containing only the structural determinants (e.g., sociodemographic background) (see Table 2). It can be seen that being a woman is significantly correlated with five out of six forms of political engagement, namely buycotting, boycotting, signing a petition, donations, and joining a voluntary organization (in line with other results for boycotting; Stolle et al. 2005; Willis and Schor 2012). Interestingly, our results for Global South activism are in contrast with the traditional gender gap in political activity (i.e., voting or party membership, among others), where men usually show higher levels of participation (Acik 2013). A separate analysis (not shown here) reveals that the division of labor in the household (e.g., who does the shopping) is not a significant explanation for the higher propensity for political consumption among women. When we include this variable in the models for buy- and boycotting, the gender-coefficient only drops marginally. In terms of age, the effects are non-uniform: While younger people sign petitions and demonstrate more often, the reverse is true for donations. The respondent's age does not affect the remaining forms of participation. Looking at income, we do observe a separation between activities that require monetary resources, such as buycotting and donations, and those that do not, with the former being positively related to income. In line with previous research, boycotting is not dependent on income, while the 
Table 2. Ordered Logit Models for Different Forms of Political Participation with Structural Variables as Independent Variables

\begin{tabular}{|c|c|c|c|c|c|c|}
\hline & Buycott & Boycott & Petition & Demonstration & Donation & Organizations \\
\hline \multirow[t]{2}{*}{ Female } & $.494^{* * *}$ & $.165^{* * *}$ & $.162^{* * *}$ & .016 & $.108^{*}$ & $.205^{* * *}$ \\
\hline & $(5.62)$ & $(3.37)$ & $(3.31)$ & $(.22)$ & $(2.14)$ & $(3.67)$ \\
\hline \multirow[t]{2}{*}{ Age } & -.003 & -.001 & $-.004^{*}$ & $-.005^{*}$ & $.010^{* * *}$ & .003 \\
\hline & $(-.96)$ & $(-.40)$ & $(-2.36)$ & $(-2.21)$ & $(6.29)$ & $(1.52)$ \\
\hline \multirow[t]{2}{*}{ Income (in $1,000 \mathrm{CHF}$ ) } & $.040^{*}$ & -.015 & $-.023^{*}$ & $-.044^{* *}$ & $.050^{* * *}$ & $-.035^{* *}$ \\
\hline & $(2.15)$ & $(-1.50)$ & $(-2.27)$ & $(-2.84)$ & $(4.60)$ & $(-2.98)$ \\
\hline \multirow[t]{2}{*}{ Education high $^{a}$} & $.258^{*}$ & $.328^{* * *}$ & $.246^{* * *}$ & $.352^{* * *}$ & $.284^{* * *}$ & $.276^{* * *}$ \\
\hline & 2.22 & $(4.89)$ & $(3.68)$ & $(3.48)$ & $(4.10)$ & $(3.63)$ \\
\hline \multirow[t]{2}{*}{ Education medium $^{a}$} & $.207^{+}$ & $.264^{* * *}$ & $.164^{*}$ & $.300^{* *}$ & $.132 *$ & $.206^{* *}$ \\
\hline & $(1.89)$ & $(4.09)$ & $(2.56)$ & 3.06 & $(2.02)$ & $(2.80)$ \\
\hline \multirow[t]{2}{*}{ Nationality } & $-.218^{+}$ & $-.145^{*}$ & $-.038^{* * *}$ & $-.306^{* *}$ & $-.278^{* * *}$ & -.100 \\
\hline & $(-1.91)$ & $(-2.16)$ & $(-5.49)$ & $(-2.91)$ & $(-4.14)$ & $(-1.30)$ \\
\hline \multirow[t]{2}{*}{ Cut 1} & $-2.311^{* * *}$ & -.186 & -.324 & $1.222^{* * *}$ & .228 & $1.158^{* * *}$ \\
\hline & $(-6.39)$ & $(-.92)$ & $(-1.60)$ & $(4.03)$ & $(1.06)$ & $(4.98)$ \\
\hline \multirow[t]{2}{*}{ Cut 2} & $-1.423^{* * *}$ & $.54^{* *}$ & $.646^{* *}$ & $1.989^{* * *}$ & $1.308^{* * *}$ & $1.869^{* * *}$ \\
\hline & $(-4.04)$ & $(2.68)$ & $(3.19)$ & $(6.45)$ & $(6.07)$ & $(7.94)$ \\
\hline $\mathrm{Chi}^{2}$ & 47.4 & 40.3 & 57.7 & 33.7 & 100.9 & 32.3 \\
\hline Pseudo- $R^{2}$ & .05 & .03 & .04 & .03 & .06 & .02 \\
\hline$N$ & 1,811 & 1,811 & 1,811 & 1,811 & 1,811 & 1,811 \\
\hline
\end{tabular}

Note: Standardized coefficients with standard errors in parentheses.

${ }^{a}$ Reference category: education low.

${ }^{+} p<.1^{*} p<.05^{* *} p<.01^{* * *} p<.001$ (two-tailed tests).

remaining forms are actually negatively affected, suggesting that these are pursued by people who lack the necessary resources for buycotting and donations (Yates 2011). This finding, then, is consistent with the argument that a fragmentation of a lifestyle of conscious consumption can occur because the different forms of political participation require different resources (cf. Lorenzen 2012). Turning to education (i.e., cultural capital), we find very consistent results, since it yields a positive effect on all forms of engagement. Finally, looking at nationality, we find that Germans living in Switzerland participate less. This is true for all activities except membership in voluntary organizations. According to Michael Nollert and Christian Huser (2009), the lower rate of political participation among foreigners is due to differences in the provision of resources, especially time and social capital. However, in the case of Germans living in Switzerland, motivations may also play an important role since attitudes in favor of Global South activism are generally lower in the German population (Schenk, Sunderer, and Rössel 2016). Taken together, these results indicate that education, nationality, and gender affect most (if not all) forms of political participation in a similar way, while we find different profiles for age and especially for income. However, as can be seen from the low values of the pseudo $R$-squared, engagement in different forms of political participation is only weakly dependent on sociodemographic background. Therefore, we now proceed to the models, that also include the motivational determinants (see Table 3).

Most of the effects of gender, age, and especially education disappear or diminish once we control for motivational variables such as attitudes and values, suggesting that the effects of the former are mediated by the motivational factors. For gender in particular we observe a substantial reduction of the effect size, suggesting that norms of prosociality and caring (reflected by ascription of responsibility, values, Global South consciousness, political orientation) are a primary reason for the higher 
Table 3. Ordered Logit Models for Different Forms of Political Participation with Structural and Motivational Variables as Independent Variables

\begin{tabular}{|c|c|c|c|c|c|c|}
\hline & Buycott & Boycott & Petition & Demonstration & Donation & Organization \\
\hline \multirow[t]{2}{*}{ Female } & $.299^{* * *}$ & .040 & .027 & -.084 & -.009 & $.112^{*}$ \\
\hline & $(3.52)$ & $(.84)$ & $(.57)$ & $(-1.25)$ & $(-.18)$ & $(1.99)$ \\
\hline \multirow[t]{2}{*}{ Age (in decades) } & -.004 & .012 & -.005 & -.003 & $.010^{* * *}$ & .002 \\
\hline & $(-.17)$ & $(.82)$ & $(-.36)$ & $(-.13)$ & $(6.17)$ & $(1.22)$ \\
\hline \multirow[t]{2}{*}{ Income (in 1,000 CHF) } & $.039^{*}$ & -.010 & $-.019^{+}$ & $-.030^{*}$ & $.050^{* * *}$ & $-.029^{*}$ \\
\hline & $(2.21)$ & $(-1.08)$ & $(-1.95)$ & $(-2.18)$ & $(4.66)$ & $(-2.54)$ \\
\hline \multirow[t]{2}{*}{ Higher education $^{a}$} & .063 & .083 & .007 & .062 & $.174^{*}$ & $.146^{+}$ \\
\hline & $(.55)$ & $(1.30)$ & $(.11)$ & $(.68)$ & $(2.49)$ & $(1.94)$ \\
\hline \multirow[t]{2}{*}{ Intermediate education $^{a}$} & .085 & .084 & -.011 & .087 & .076 & $.140^{+}$ \\
\hline & $(.80)$ & $(1.39)$ & $(-.18)$ & $(.98)$ & $(1.16)$ & $(1.93)$ \\
\hline \multirow[t]{2}{*}{ Nationality } & $-.228^{*}$ & $-.136^{*}$ & $-.383^{* * *}$ & $-.262^{* *}$ & $-.278^{* * *}$ & -.111 \\
\hline & $(-2.10)$ & $(-2.14)$ & $(-5.96)$ & $(-2.77)$ & $(-4.21)$ & $(-1.48)$ \\
\hline \multirow[t]{2}{*}{ Leftist political orientation $^{b}$} & $.370^{* * *}$ & $.216^{* *}$ & $.368^{* * *}$ & $.620^{* * *}$ & -.043 & .093 \\
\hline & $(3.30)$ & $(3.15)$ & $(5.17)$ & $(4.16)$ & $(-.57)$ & $(1.10)$ \\
\hline \multirow[t]{2}{*}{ Centrist political orientation ${ }^{b}$} & .107 & .012 & $.156^{*}$ & $.275^{+}$ & -.048 & -.016 \\
\hline & $(1.09)$ & $(.17)$ & $(2.13)$ & $(1.72)$ & $(-.64)$ & $(-.19)$ \\
\hline \multirow[t]{2}{*}{ Religiosity high $^{c}$} & .026 & .048 & .024 & $-.351^{*}$ & $.387^{* * *}$ & $.718^{* * *}$ \\
\hline & $(.18)$ & $(.55)$ & $(.28)$ & $(-2.19)$ & $(3.74)$ & $(7.46)$ \\
\hline \multirow[t]{2}{*}{ Religiosity medium $^{c}$} & .011 & -.028 & -.041 & $-.126^{+}$ & .040 & $.163^{* *}$ \\
\hline & $(.13)$ & $(-.56)$ & $(-.83)$ & $(-1.85)$ & $(.77)$ & $(2.77)$ \\
\hline \multirow[t]{2}{*}{ Global South consciousness } & $.296^{* * *}$ & $.242^{* * *}$ & $.204^{* * *}$ & $.118^{*}$ & $.233^{* * *}$ & $.199^{* * *}$ \\
\hline & $(4.94)$ & $(6.51)$ & $(5.36)$ & $(2.05)$ & $(5.87)$ & $(4.30)$ \\
\hline \multirow[t]{2}{*}{ Responsibility consumer } & $.182^{* * *}$ & $.179^{* * *}$ & $.121^{* * *}$ & $.108^{*}$ & $.077^{*}$ & .029 \\
\hline & $(3.78)$ & $(6.33)$ & $(4.24)$ & $(2.55)$ & $(2.49)$ & $(.85)$ \\
\hline \multirow[t]{2}{*}{ Responsibility institutions } & -.027 & $.121^{* * *}$ & $.132^{* * *}$ & $.097^{+}$ & $.098^{* *}$ & $.096^{*}$ \\
\hline & $(-.50)$ & $(3.45)$ & $(3.69)$ & $(1.78)$ & $(2.69)$ & $(2.27)$ \\
\hline \multirow[t]{2}{*}{ Responsibility worker } & .017 & .019 & .035 & .032 & -.007 & $.056^{+}$ \\
\hline & $(.40)$ & $(.73)$ & $(1.38)$ & $(.88)$ & $(-.24)$ & $(1.91)$ \\
\hline \multirow[t]{2}{*}{ Universalism } & .140 & $.304^{* * *}$ & $.339^{* * *}$ & $.349^{* * *}$ & $.159^{* *}$ & $.196^{* *}$ \\
\hline & $(1.52)$ & $(5.61)$ & $(6.22)$ & $(4.56)$ & $(2.72)$ & $(3.09)$ \\
\hline \multirow[t]{2}{*}{ Benevolence } & .018 & -.012 & $.182^{* * *}$ & $.197^{* *}$ & $.135^{* *}$ & $.201^{* * *}$ \\
\hline & $(.24)$ & $(-.27)$ & $(4.15)$ & $(3.18)$ & $(2.88)$ & $(3.89)$ \\
\hline \multirow[t]{2}{*}{ Self-direction } & .031 & $.172^{* * *}$ & $.192^{* * *}$ & $.248^{* * *}$ & .041 & $.167^{* * *}$ \\
\hline & $(.54)$ & $(5.09)$ & $(5.68)$ & $(5.07)$ & $(1.13)$ & $(4.27)$ \\
\hline \multirow[t]{2}{*}{ Cut 1} & 1.357 & $4.412^{* * *}$ & $4.185^{* * *}$ & $5.538^{* * *}$ & $3.287^{* * *}$ & $4.426^{* * *}$ \\
\hline & $(1.86)$ & $(9.67)$ & $(9.24)$ & $(7.53)$ & $(7.38)$ & $(8.70)$ \\
\hline \multirow[t]{2}{*}{ Cut 2} & $2.321^{* *}$ & $5.301^{* * *}$ & $5.339^{* * *}$ & $6.380^{* * *}$ & $4.454^{* * *}$ & $5.196^{* * *}$ \\
\hline & $(3.19)$ & $(11.49)$ & $(11.62)$ & $(8.62)$ & $(9.87)$ & (10.13) \\
\hline $\mathrm{Chi}^{2}$ & 192.1 & 465.4 & 437.9 & 228.7 & 267.9 & 193.5 \\
\hline Pseudo- $R^{2}$ & .19 & .26 & .26 & .18 & .16 & .13 \\
\hline$N$ & 1,811 & 1,811 & 1,811 & 1,811 & 1,811 & 1,811 \\
\hline
\end{tabular}

Note: Standardized coefficients with standard errors in parentheses.

${ }^{a}$ Reference category: lower education.

${ }^{b}$ Reference category: right-wing political orientation.

${ }^{c}$ Reference category: religiosity low.

${ }^{\dagger} p<.1{ }^{*} p<.05^{* *} p<.01{ }^{* * *} p<.001$ (two-tailed tests). 

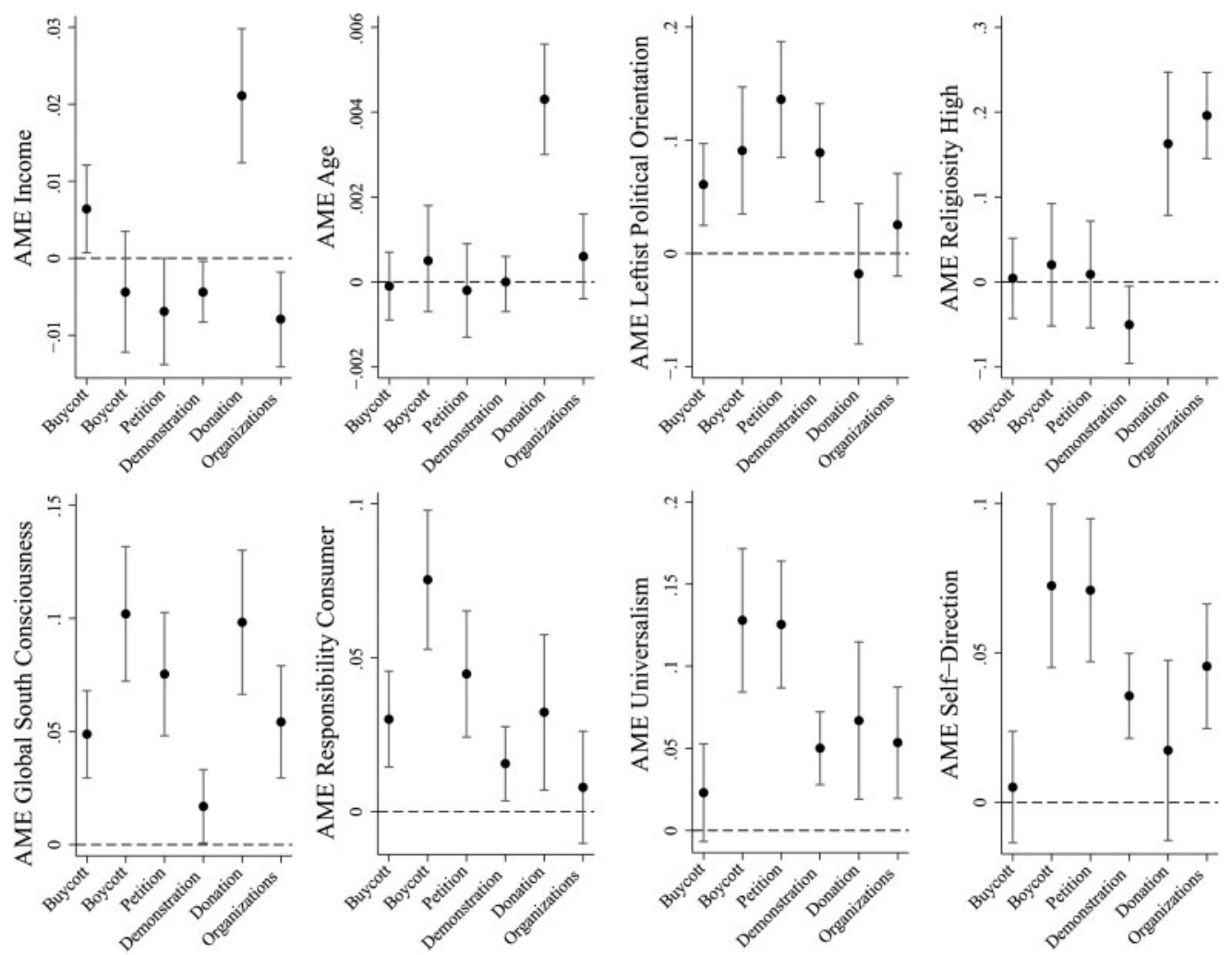

Figure 2. Plots of Average Marginal Effects (AME) with 95\% Confidence Intervals for the Highest Category (yes, several times/regularly)

Notes: Based on the ordered logit models (see Table 3), with different forms of political participation as dependent variables, grouped by determinants. All independent variables were included for the computation but only selected determinants are presented here. $N=1,811$.

propensity to consume politically among women. However, in contrast to these variables, the effects of income and nationality are surprisingly robust, as they remain largely unchanged (in terms of direction and level of significance). Furthermore, when we compare the AME for income and age between the different models (see Figure 2), it is striking that these determinants are much more important for donations than for any other form of participation.

Turning to the motivational determinants, we find that political orientation is statistically significant in four cases. Politically left-wing individuals participate more in buycotts, boycotts, petitions, and demonstrations. However, they are not more likely to give donations or participate in voluntary organizations. We see more or less a mirror image when we look at religiosity. High religiosity has a statistically significant positive impact on donations and on participation in voluntary organizations. This is a plausible result, given that money donated in churches often goes to causes for the Global South, and many voluntary organizations in the sector of development aid in Switzerland have links to churches. A prominent Swiss example in this regard is "Fastenopfer," a Catholic relief organization that primarily helps poor people in the Global South with donations from its members (Fuchs and Padrão 2012). Interestingly, however, religious individuals tend to abstain from the most confrontational form of political participation included, i.e., demonstrations. This difference between politically and religiously driven activities becomes even more apparent when we look at the AME plots in Figure 2. While the confidence intervals for a left-wing political orientation cut across the zero baseline in the case of donations and organizations (in contrast to the remaining forms of participation), 
the reverse is true for higher levels of religiosity. We thus have to conclude, in relation to the civic voluntarism model, that participation in churches only fosters certain forms of political engagement for the Global South. However, religiosity does not deter individuals from helping distant others, i.e., people in the Global South. In terms of political orientation, we can speculate that a leftist orientation not only entails a skeptical assessment of the North-South divide but also reflects a progressive view that places emphasis on newness and independent thought. These characteristics would be more in line with forms of political engagement that directly target social change (buycotts, boycotts, petitions, demonstrations) (Datler, Jagodzinski, and Schmidt 2013).

Finally, we look at the remaining attitudinal and value-related motivations underlying Global South activism. Global South consciousness is a fairly clear-cut case, as it has a significantly positive impact on all forms of political activism. However, as can be seen in Figure 2, Global South consciousness is less important for demonstrations, and also to a certain extent for buycotting and joining voluntary organizations, than it is for boycotting and donations. Furthermore, political activism increases if responsibility for the conditions in the Global South is attributed to consumers in First World countries or to institutions. This correlation is especially strong for boycotting (see Figure 2). The same is true for the three value orientations included in the regression, which all tend to encourage political activism: Universalism is relevant for all forms of participation apart from buycotting, benevolence has a positive impact on all activities other than the two forms of political consumption, and finally, self-direction has a positive influence on all forms except for buycotting and donations. Turning to the AME, however, we find that the values of universalism and self-direction have a stronger effect on boycotting and signing petitions than on the other forms.

To summarize these results, three major empirical patterns stand out, clearly demonstrating that the different forms of political participation are not determined by the same sociodemographic and motivational variables. Firstly, when we look at the structural determinants we can see that buycotting and especially donations are the only forms that are driven by greater monetary resources. Secondly, we find one set of items linked to religiosity (donations and participation in voluntary groups), and another clearly demarcated set of items linked to a left-wing political orientation (buycott, boycott, petitions, demonstrations). Finally, buycotting - in contrast to all other forms of Global South activism-is not directly driven by values. Thus our analysis of the determinants of activism for the Global South also suggests that there is no coherent lifestyle of conscious consumption. Instead the pattern of activism for the Global South is fragmented (cf. Brown 2009; Ehrich and Irwin 2005; Lorenzen 2012). In line with the theoretical argument above, this fragmentation can be traced back to the resources and motivational orientations associated with different forms of political participation. While education and the Global South consciousness in particular relate positively to all forms of political engagement and therefore seem to facilitate a lifestyle of conscious consumption, economic capital (income), social capital (religiosity), political orientation, and values tend to fragment it. Different forms of participation are thus sustained by different social groups with different motivational orientations.

\section{CONCLUSION AND DISCUSSION}

Political consumption is not only a major field of research, but also a social phenomenon of growing importance, since more and more people in Western countries tend to be active in the two major forms, buycotting and boycotting (Dalton 2008; Koos 2012; Stolle et al. 2005). However, several scholars have pointed to possible drawbacks of political consumption, suggesting that it may have negative effects on more active forms of political participation, and on more radical attempts at institutional transformation (Bennett 1998; Szasz 2007, 2012). Some have even interpreted it as a form of ethical class distinction where upper-middle class consumers oscillate between ethical and aesthetic concerns and create symbolic boundaries towards lower class consumers (Adams and Raisborough 2008; Johnston and Baumann 2010). In this article, we have focused on the so-called crowding-out 
thesis: does political consumption lead to decreasing participation in other forms of political engagement, or is it, as some researchers on political consumption argue, part of a coherent lifestyle of conscious consumption and participation?

Our results stand between the two extremes mentioned above: They neither indicate a crowding out of other forms of participation, nor do they show a coherent lifestyle of conscious consumption and participation. What they show is a fragmented pattern of Global South activism. Based on the PCA and MCA, we find that all our measures of Global South activism are part of one dimension; however, the two more mainstream forms of activism — donating and buycotting-load rather weakly on this factor and are fairly undifferentiated in the space of Global South activism. This indicates that for most consumers in our sample political consumption in the form of buycott does not spill over into more challenging forms of political activism. Only a subgroup of respondents combines political consumption with other forms of political engagement. In general, political consumption in the form of buycott does not differ much from donations, suggesting that they may be thought of as complements.

The analysis of the determinants of activism for the Global South also shows a mixed pattern. Buycotting in particular seems to be quite distinct from other forms of political participation, since we find that it is more dependent on income than any other form except donations, however, more driven by political considerations than donations and participation in voluntary organizations, and not directly influenced by values. Boycotting seems to be more in line with other forms, although it is not related to income at all and is not driven by benevolence values. Thus, our results do not support the idea that political consumption is partially driven by distinction strategies of the middle and upper class (Adams and Raisborough 2008; Johnston and Baumann 2010). Buycotting is connected to income, but the two forms of political consumption seen together are not closely linked to indicators of class or status (income, education), but, instead, are connected to political orientation, attitudes, and values. Furthermore, boycott and buycott clearly differ in their alignment with other forms of participation and in their determinants. Therefore, it is open for future discussion whether they form a coherent pattern of political consumption.

In general, we find separated forms of participation linked to (1) the monetary resources of a household (buycott and donation), (2) a left-wing political orientation on the one hand (buycott, boycott, petition, demonstration) and a religious worldview on the other (donation and membership of voluntary organizations), and finally (3) the value orientation of an individual (all except buycott). Thus, instead of forming a coherent political lifestyle, Global South activism is fragmented into clearly differentiated patterns. Our analysis of the determinants of political engagement has furthermore shown that sociodemographic variables like age, gender, and education are linked to political participation mainly via attitudes and values. Therefore, future research on participation should much more clearly disentangle between the resource-based and the attitude-based determinants of political engagement. At least sociodemographic differences in our study seem to be driven mainly by attitudebased differences.

\section{REFERENCES}

Acik, Necla. 2013. “Reducing the Participation Gap in Civic Engagement: Political Consumerism in Europe.” European Sociological Review 29:1309-22.

Adams, Matthew and Jayne Raisborough. 2008. "What Can Sociology Say About Fair Trade? Class, Reflexivity, and Ethical Consumption.” Sociology 42:1165-82.

Ajzen, Icek and Nicole G. Cote. 2008. “Attitudes and the Prediction of Behavior." Pp. 289-311 in Attitudes and Attitude Change, edited by W. Crano and R. Prislin. New York: Psychology Press.

Andorfer, Veronika A. and Ulf Liebe. 2012. "Research on Fair Trade Consumption - A Review." Journal of Business Ethics 106:415-35.

attac-bern. n.d. attac. Eine andere Welt ist möglich! Retrieved March 29, 2016 (www.attac-bern.ch/fileadmin/doku mente/attac-bern/Text_Flugi_attacbe_neu.pdf). 
Bair, Jennifer and Palpacuer. Florence 2012. "From Varieties of Capitalism to Varieties of Activism: The Antisweatshop Movement in Comparative Perspective." Social Problems 59:522-43.

Balderjahn, Ingo, Mathias Peyer, and Marcel Paulssen. 2013. "Consciousness for Fair Consumption: Conceptualization, Scale Development, and Empirical Calidation.” International Journal of Consumer Studies 37:546-55.

Balsiger, Philip. 2010. "Making Political Consumers: The Tactical Action Repertoire of a Campaign for Clean Clothes." Social Movement Studies 9:311-29.

- 2012. "Competing Tactics. How the Interplay of Tactical Approaches Shapes Movement Outcomes on the Market for Ethical Fashion.” MPIFG Discussion Paper 12/9. Max Planck Institute for the Study of Societies, Cologne, Germany.

Barnett, Clive, Paul Cloke, Nick Clarke, and Alice Malpass. 2005. "Consuming Ethics: Articulating the Subjects and Spaces of Ethical Consumption." Antipode 37:23-45.

Baumann, Shyon, Athena Engman, and Josée Johnston. 2015. "Political Consumption, Conventional Politics, and High Cultural Capital.” International Journal of Consumer Studies 39:413-21.

Beck, Ulrich. 1997. The Reinvention of Politics: Rethinking Modernity in the Global Social Order. Cambridge, UK: Polity Press.

Bennett, Lance W. 1998. "1998 Ithiel De Sola Pool Lecture: The UnCivic Culture: Communication, Identity, and the Rise of Lifestyle Politcs.” Political Science and Politics 31:740-61.

Bierhoff, Hans-Werner. 2002. Prosocial Behaviour. New York: Psychology Press.

Blamey, Russel. 1998. “The Activation of Environmental Norms: Extending Schwartz's Model.” Environment and Behavior 30:676-708.

Brown, Keith R. 2009: “The Social Dynamics and Durability of Moral Boundaries.” Sociological Forum 24:854-76.

Coffé, Hilde and Catherine Bolzendahl. 2010. "Same Game, Different Rules? Gender Differences in Political Participation.” Sex Roles 62:318-33.

Dalton, Russell J. 2008. “Citizenship Norms and the Expansion of Political Participation.” Political Studies 56:76-98.

Datler, Georg, Wolfgang Jagodzinski, and Peter Schmidt. 2013. "Two Theories on the Test Bench: Internal and External Validity of the Theories of Ronald Inglehart and Shalom Schwartz.” Social Science Research 42:906-25.

DeVault, Marjorie L. 1991. Feeding the Family. The Social Organization of Caring as Gendered Work. Chicago: The University of Chicago Press.

Dillman, Don A. 2000. Mail and Internet Survey. The Tailored Design Method. New York: J. Wiley.

Doran, Caroline J. 2009. “The Role of Personal Values in Fair Trade Consumption." Journal of Business Ethics 84:549-63.

Ehrich, Kristine R. and Julie R. Irwin. 2005. "Willful Ignorance in the Request for Product Attribute Information." Journal of Marketing Research 42:266-77.

Fairtrade International (FLO). 2012. "For Producers, with Producers.” Annual Report 2011-12. Retrieved February 28, 2015 (www.fairtrade.net/fileadmin/user_upload/content/2009/resources/2011-12_AnnualReport_web_version_ small_FairtradeInternational.pdf).

Fuchs, Elisa and Luciano Padrão. 2012. "Relevance and Effects of Action in the Faith and Justice Field. Seeking to Identify, Assess and Document Results and Impacts of the Work of Fastenopfer's Partners." Fastenopfer. Retrieved August 18, 2016 (https://fastenopfer.ch/content/uploads/2016/06/Fastenopfer-FJ-Study_Final.pdf).

Jaffee, Daniel. 2012. "Weak Coffee Certification and Co-Optation in the Fair Trade Movement." Social Problems 59:94-116.

Johnston, Josée and Michelle Szabo. 2011. "Reflexivity and the Whole Food Market Consumer: The Lived Experience of Shopping for Change." Agriculture and Human Values 28:303-19.

Johnston, Josée and Shyon Baumann. 2010. Foodies: Democracy and Distinction in the Gourmet Foodscape. New York: Routledge.

Koos, Sebastian. 2012. "What Drives Political Consumption in Europe? A Multi-Level Analysis on Individual Characteristics, Opportunity Structures.” Acta Sociologica 55:37-57.

Le Mare, Ann. 2008. "The Impact of Fair Trade on Social Economic Development: A Review of the Literature." Geography Compass 2:1922-42.

Le Roux, Brigitte and Henry Rouanet. 2010. Multiple Correspondence Analysis. Thousand Oaks, CA: Sage Publications. Lorenzen, Janet A. 2012. “Going Green: The Process of Lifestyle Change.” Sociological Forum 27:94-116.

Ma, Yoon Jin and Hyun-Hwa Lee. 2011. "Understanding Consumption Behaviours for Fair Trade Non-Food Products: Focusing on Self-Transcendence and Openness to Change Values.” International Journal of Consumer Studies. Retrieved May 17, 2017 (doi: 10.1111/j.1470-6431.2011.01037.x). 
Mahé, Thuriane. 2010. "Are Stated Preferences Confirmed by Purchasing Behaviours? The Case of Fair TradeCertified Bananas in Switzeland.” Journal of Business Ethics 92:301-15.

Max Havelaar 2002. Max Havelaar Report. Fair trade. Jahresbericht 2001. Retrieved August 16, 2016 (www.maxhave laar.ch/newsroom/materialien.html).

Max Havelaar. 2012. Max Havelaar-Stiftung (Schweiz). Jahresbericht 2011. Retrieved March 29, 2016 (www.maxhave laar.ch/fileadmin/user_upload/publikationen/mh12_JB2011_d.pdf).

Mazar, Nina and Chen-Bo Zhong. 2010. “Do Green Products Make Us Better People?” Psychological Science 21:494-98.

Micheletti, Michele. 2010. Political Virtue and Shopping. Individuals, Consumerism, and Collective Action. New York: Palgrave Macmillan.

Micheletti, Michele and Dietlind Stolle. 2005. "Swedish Political Consumers: Who They Are and Why They use the Market as an Arena for Politics.” Pp. 145-64 in Political Consumerism: Its Motivations, Power, and Conditions in the Nordic Countries and Elsewhere. Proceedings from the 2nd International Seminar on Political Consumerism, Oslo August 26-29, 2004, edited by M. Boström, A. Føllesdal, M. Klintman, M. Micheletti, and M.P. Sørensen. Kopenhagen: TemaNord.

Mitchell, Michael N. 2010. Data Management Using Stata: A Practical Handbook. College Station, TX: Stata Press.

Monin, Benoît and Dale T. Miller. 2001. "Moral Credentials and the Expression of Prejudice." Journal of Personality and Social Psychology 81:33-43.

Mood, Carina. 2010. "Logistic Regression: Why We Cannot Do What We Think We Can Do, and What We Can Do About It.” European Sociological Review 26:67-82.

Newholm, Terry and Deirdre Shaw. 2007. "Studying the Ethical Consumer: A Review of Research." Journal of Consumer Behavior 6:253-70.

Nollert, Michael and Christian Huser. 2009. "Freiwilligenmarkt Schweiz: Chancen und Potenziale." VerbandsManagement 35:38-49.

Omeje, Kenneth. 2008. "Extractive Economies and Conflicts in the Global South: Re-Engaging Rentier Politics." Pp. 1-26 in Extractive Economies and Conflicts in the Global South: Multi-Regional Perspectives on Rentier Politics, edited by K. Omeje. Aldershot, UK: Ashgate.

Preisendörfer, Peter and Axel Franzen. 1996. "Der schöne Schein des Umweltbewusstseins. Zu den Ursachen und Konsequenzen von Umwelteinstellungen in der Bevölkerung.” Pp. 219-44 in Umweltsoziologie. Sonderheft Kölner Zeitschrift für Soziologie und Sozialpsychologie 36, edited by A. Diekmann and C.C. Jaeger. Opladen, Germany: Westdeutscher Verlag.

Preston, Jesse L., Ryan S. Ritter, and J. Ivan Hernandez. 2010. "Principles of Religious Prosociality: A Review and Reformulation.” Social and Personality Psychology Compass 4:574-90.

Raynolds, Laura T. 2002. "Consumer/Producer Links in Fair Trade Coffee Networks.” Sociologia Ruralis 42:404-24.

Sachdeva, Sonya, Rumen Iliev, and Douglas L. Medin. 2009. "Sinning Saints and Saintly Sinners. The Paradox of Moral Self-Regulation." Psychological Science 20:523-28.

Schenk, Patrick, Georg Sunderer, and Jörg Rössel. 2016. "Sind Deutschschweizer altruistischer als Deutsche? Ein Vergleich des Konsums fair gehandelter Produkte in Deutschland und der Schweiz.” Berliner Journal für Soziologie 26:145-70.

Schulthess, Jeremias. 2015. "Erfolgreiches Polit-Engagement ist bloss einen Klick entfernt.” Tages Woche, January 30. Retrieved March 29, 2016 (www.tageswoche.ch/de/2015_05/schweiz/679363/).

Schwartz, Shalom. 1977. "Normative Influences on Altruism.” Advances in Experimental Social Psychology 10:221-79.

—. 2007. "Value Orientations: Measurements, Antecedents, and Consequences Across Nations." Pp. 169-97 in Measuring Attitudes Cross-Nationally. Lessons from the European Social Survey, edited by R. Jowell, C. Roberts; R. Fitzgerald, and E. Gillian. Los Angeles: SAGE.

Stern, Paul C., Thomas Dietz, Troy Abel, Gregory Guagnano, and Linda A. Kalof. 1999. "A Value-Belief-Norm Theory of Support for Social Movements: The Case of Environmentalism.” Human Ecology Review 6:81-97.

Stolle, Dietlind, Marc Hooghe, and Michele Micheletti. 2005. "Politics in the Supermarket: Political Consumerism as a Form of Political Participation.” International Political Science Review 26:245-69.

Summers, Nik. 2016. "Ethical Consumerism in Global Perspective: A Multilevel Analysis of the Interactions Between Individual-Level Predictors and Country-Level Affluence.” Social Problems 63:303-28.

Sunderer, Georg and Rössel. Jörg 2012. "Morality or Economic Interest? The Impact of Moral Motives and Economic Factors on the Purchase of Fair Trade Groceries." International Journal of Consumer Studies 36:244-50.

Szasz, Andrew. 2007. Shopping Our Way to Safety: How We Changed from Protecting the Environment to Protecting Ourselves. Minneapolis: University of Minnesota Press.

—. 2012. "Forum Comment by Andrew Szasz.” Pp. 75-79 in: Shopping for Good, edited by D. O’Rourke. Cambridge, UK: MIT Press. 
Ulrich, Sylvana. 2013. “Eine Woche ohne Nestlé.” NZZ Campus, July 7. Retrieved March 29, 2016 (http://campus.nzz. ch/alltagskulturen/eine-woche-ohne-nestle).

Verba, Sidney, Kay L. Schlozman, and Henry E. Brady. 1995. Voice and Equality: Civic Voluntarism in American Politics. Cambridge, MA: Harvard University Press.

Wilkinson, John. 2007. "Fair Trade: Dynamic and Dilemmas of a Market Oriented Global Social Movement." Journal of Consumer Policy 30:219-39.

Willis, Margaret M. and Juliet B. Schor. 2012. "Does Changing a Light Bulb Lead to Changing the World? Political Action and the Conscious Consumer." The Annals of the American Academy of Political and Social Science 644:160-90.

Yates, Luke. 2011. “Critical Consumption.” European Societies 13:191-217. 